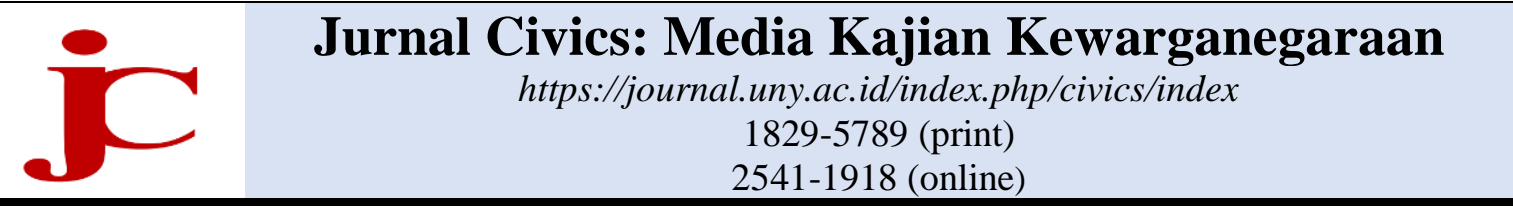

\title{
Model desain Pendidikan Kewarganegaraan di era media digital sebagai pendukung implementasi pendidikan karakter
}

\author{
Anita Trisiana $^{\text {a.1* }}$, Sugiaryo ${ }^{\text {b.2 }}$, Rispantyo ${ }^{\text {c.3 }}$ \\ a,b,c Program Studi PPKn, FKIP, Universitas Slamet Riyadi, Surakarta, Indonesia. \\ 1anita.trisiana@gmail.com*; ${ }^{2}$ sugiaryo17@gmail.com; ${ }^{3}$ rispantyo@yahoo.co.id \\ *korespondensi penulis
}

\begin{tabular}{ll}
\hline \multicolumn{2}{l}{ Informasi Artikel } \\
\hline Sejarah artikel & \\
Diterima & $: 05-05-2019$ \\
Revisi & $: 10-09-2019$ \\
Dipublikasikan & $: 31-10-2019$ \\
\hline
\end{tabular}

\begin{abstract}
ABSTRAK
Artikel ini bertujuan untuk membedah desain model pembelajaran. Metode penelitian menggunakan penelitian dan pengembangan Research and Development (R\&D) dengan menggunakan model pengembangan prosedural mengadaptasi model ADDIE (Analyze, Design, Develop, Implement, and Evaluation). Hasil penelitian menunjukkan sebagai berikut: pertama, analysis, yaitu melakukan analisis kebutuhan, mengidentifikasi masalah (kebutuhan), dan melakukan analisis tugas. Kedua, design, tahap desain ini, merumuskan tujuan pembelajaran. Ketiga, development, adalah proses mewujudkan blue-print dengan inovasi media digital. Keempat, implementation, adalah langkah nyata untuk menerapkan sistem pembelajaran yang sedang kita buat. Kelima, evaluation, yaitu proses untuk melihat apakah sistem pembelajaran yang sedang dibangun berhasil, sesuai dengan harapan awal atau tidak. Berdasarkan pengembangan instruksional model ADDIE tersebut kemudian diadopsi dalam tahapan pengembangan model pembelajaran Pendidikan Kewarganegaraan dengan nama MPC (Modification of Project Citizen) yang relevan di era media digital dan dikembangkan berdasarkan implementasi pendidikan karakter dan ketercapaian kompetensi Pendidikan Kewarganegaraan.
\end{abstract}

Kata kunci:

Desain PKn

Media digital

Pendidikan karakter

\section{Keywords:}

Civic Education Instructional design

Digital Media

Character Education

\section{ABSTRACT}

This research aims to explain the design of Citizenship Education Learning Model. The research method uses research and development (Research and Development $(R \& D)$ and adopt the ADDIE model (Analyze, Design, Develop, Implement, Evaluation) The sample in this study involved state and private universities in Central Java. The results of the study, first, Analysis is to do a needs analysis, identify problems (needs), and perform task analysis. The design phase is to formulate learning objectives. Third, development is the process of creating blueprint with digital media innovation. Fourth, implementation is a real step to implement the learning system that we are making. Fifth, evaluation is a process to see whether the learning system succeed, according to initial expectations or not. Based on the ADDIE model instructional development, it was later adopted in the stages of developing the Citizenship Education learning model, with the modification of MPC (Modification of Project Citizen) relevant in the era of digital media and developed based on the implementation of character education and achievement of competencies in Citizenship Education.

\section{Copyright $\odot 2019$ Anita Trisiana, dkk}

\section{Pendahuluan}

Praktik pendidikan di Indonesia selama ini lebih banyak fokus pada pengembangan keterampilan dan ilmu pengetahuan dibandingkan dengan pengembangan karakter luhur dan rasa kebangsaan warga negara. Selama ini tampak bahwa pendidikan di Indonesia terlalu menekankan aspek 
intelektual namun kurang memperhatikan aspek moralitas.

Semakin canggihnya teknologi digital masa kini membuat perubahan besar terhadap dunia. Dunia telah mengalami empat tahapan revolusi, yaitu: 1) Revolusi Industri 1.0 terjadi pada abad ke 18 melalui penemuan mesin uap, sehingga memungkinkan barang dapat diproduksi secara massal, 2) Revolusi Industri 2.0 terjadi pada abad ke 19-20 melalui penggunaan listrik yang membuat biaya produksi menjadi murah, 3) Revolusi Industri 3.0 terjadi pada sekitar tahun 1970-an melalui penggunaan komputerisasi, dan 4) Revolusi Industri 4.0 sendiri terjadi pada sekitar tahun 2010-an melalui rekayasa intelegensia dan internet of thing sebagai tulang punggung pergerakan dan konektivitas manusia dan mesin.

Lahirnya berbagai macam teknologi digital yang semakin maju telah banyak bermunculan. Berbagai kalangan menikmati kemudahan dalam mengakses suatu informasi melalui banyak cara serta dapat menikmati fasilitas dari teknologi digital dengan bebas. Generasi muda memanfaatkan internet secara aktif dengan cara-cara yang mungkin berkontribusi pada keterlibatan sipilnya (Martens \& Hobbs, 2015). Namun disayangkan semakin berkembangnya teknologi justru semakin banyaknya kejahatan yang terdeteksi. Meskipun telah ada manfaat besar untuk masyarakat dari revolusi digital terutama dalam hal aksesibilitas informasi ada sejumlah kekhawatiran. Kekuatan diperluas komunikasi dan berbagi informasi, meningkatkan kemampuan untuk teknologi yang sudah ada, dan munculnya teknologi baru membawa dengan itu banyak peluang potensial untuk eksploitasi. Revolusi digital membantu mengantar era baru pengawasan massal menghasilkan berbagai baru sipil dan isu hak asasi manusia

Dalam era modern kombinasi antara internet dan komputasi personal menyebabkan media digital membawa dampak dan masalah dalam dunia penerbitan, jurnalistik, hiburan, pendidikan, perdagangan dan politik. Media digital juga telah menimbulkan tantangan baru terutama bagi hukum yang melindungi hak cipta dan kekayaan intelektual dan dalam gerakan konten terbuka di mana pencipta konten dengan sukarela menyerahkan sebagian atau seluruh hak-hak hukum mereka untuk pekerjaan mereka. Kini media digital sudah memasuki sendi-sendi kehidupan masyarakat dan dampaknya telah terasa bagi masyarakat luas yang menunjukkan bahwa media digital adalah awal sebuah era baru dalam sejarah industri yang disebut era Informasi dan telah mengarah ke masyarakat paperless, yakni semua produk informasi pada media yang diproduksi dan dikonsumsi berbasis komputer. Namun tantangan menuju transisi media digital termasuk produk undangundang yang mengatur hak cipta, sensor, dan digital divide adalah momok menuju era kegelapan digital (digital dark age) karena media yang lebih tua menjadi tidak dapat diakses ke sistem baru atau tidak bisa diupgrade ke sistem informasi.

Revolusi teknologi telah mengubah cara pandang seseorang dalam menjalani kehidupan yang sangat canggih saat ini. Sebuah teknologi yang membuat perubahan besar kepada seluruh dunia, dari mulai membantu mempermudah segala urusan sampai membuat masalah karena tidak bisa menggunakan fasilitas digital yang semakin canggih ini dengan baik dan benar. Dengan demikian kemandirian dan daya saing bangsa dapat tercapai jika dilakukan dalam rangka memajukan peradaban bangsa Indonesia. Salah satunya melalui pengembangan sistem nasional ilmu pengetahuan dan teknologi dalam Pendidikan Kewarganegaraan. Pendidikan Kewarganegaraan merupakan salah satu mata ajar yang membentuk karakter masyarakat Indonesia. Sebagai suatu sistem pengetahuan terintegrasi, pendidikan kewarganegaraan dalam konteks ilmiah memiliki logika internal atau struktur keilmuan yang mencakup tiga dimensi interaktif, yaitu kajian ilmiah (academic civics) tentang sikap, pengetahuan, dan keterampilan pemberdayaan kewarganegaraan, sosial-kultural kewarganegaraan dalam masyarakat (community civics), dan pembelajaran sikap, pengetahuan dan sikap kewarganegaraan dalam pendidikan formal dan nonformal 
(Winataputra, 2001, 2015). Bahkan kini, berkembang pula pengembangan sikap, pengetahuan, dan keterampilan kewarganegaraan untuk birokrasi/kelembagaan (Sapriya, 2015). Pendidikan kewarganegaraan sebagai kajian politik tidak berorientasi untuk mendukung rezim atau kekuatan politik tertentu yang merupakan orientasi dari teori hegemonik (hegemonic theory) (Prewitt, Dawson, \& Dawson, 1977). Konsekuensi pendidikan kewarganegaraan sebagai pendidikan politik formal memiliki tujuan untuk membina dan mengembangkan warga negara yang baik, yakni warga negara yang mampu berpartisipasi serta bertanggung jawab dalam kehidupan berbangsa dan bernegara.

Kampus yang memiliki karakter Pancasila akan menanamkan karakter itu kepada para mahasiswa. Bila hal itu terwujud, perguruan tinggi akan melahirkan generasi penerus yang memiliki karakter yang dibutuhkan untuk membangun dan menyejahterakan bangsa. Pendidikan karakter bersifat khas individual sehingga perlu memperhatikan potensi diri yang dimiliki individu atau berbasis potensi diri. Pendidikan karakter berbasis potensi diri (individu) merupakan pendidikan yang tidak saja membimbing dan membina setiap anak didik untuk memiliki kompetensi intelektual, keterampilan mekanik, produktif, inovatif, dan pembangunan karakter.

Aslan (2011) menyebutkan karakter terdiri dari nilai operatif dan nilai dalam tindakan. Kita berproses dalam karakter kita seiring suatu nilai menjadi suatu kebaikan, suatu disposisi batin yang dapat diandalkan untuk menanggapi situasi dengan cara yang menurut moral itu baik. Karakter yang terasa demikian memiliki tiga bagian yang saling berhubungan, yakni pengetahuan moral, perasaan moral, dan perilaku moral. Karakter yang baik terdiri dari mengetahui hal yang baik, menginginkan hal yang baik dan melakukan hal yang baik, kebiasaan dalam berfikir, kebiasaan dalam hati, dan kebiasaan dalam tindakan. Ketiga hal ini diperlakukan untuk mengarahkan suatu kehidupan moral dan ketiganya membentuk kedewasaan moral.
Karakter baik yang dirumuskan oleh para penganut ajaran Aristoteles (Arsitotelian) terutama di Inggris mencakup (1) kebajikan moral (seperti kejujuran dan kebaikan), (2) kebajikan sipil (layanan masyarakat), (3) kebajikan intelektual (rasa ingin tahu, kreativitas), dan (4) kebajikan kinerja (ketekunan dan ketekunan) (Arthur, Kristjánsson, Harrison, Sanderse, \& Wright, 2016; Arthur et al., 2015; Carr, Arthur, \& Kristjánsson, 2017). Untuk mengatasi egoisme dari pendekatan psikologis, para sarjana Jubilee Center mempromosikan pendidikan karakter yang bertujuan untuk meningkatkan kepekaan peserta didik terhadap orang lain, kemampuan untuk mengidentifikasi pilihan-pilihan yang buruk secara moral, dan kemampuan untuk berpikir tentang justifikasi tindakan mereka sendiri (Arthur et al., 2015).

Berdasarkan hasil penelitian pada tahun 2015 bahwa "perguruan tinggi memiliki peranan strategis dalam implementasi pendidikan karakter, yang terintegrasi dalam pelaksanaan pembelajaran secara integratif" (Trisiana, Jutmini, Haryati, \& Hidayatullah, 2015). Berdasarkan hasil penelitian tersebut perlu ada tidak lanjut inovasi pembelajaran dengan mengembangkan model pembelajaran berbasis pendidikan karakter (Trisiana, 2016). Selanjutnya evaluasi pelaksanaan pembelajaran general education sebagai pengembang kepribadian di berbagai perguruan tinggi yang dibahas dalam pelaksanaan Focus Group Discussion ditemukan data sebagai berikut, pertama, UPT MKU setiap universitas perlu melakukan terobosan baru dalam mengembangkan pelaksanaan pembelajaran yang memberikan penguatan terhadap ciri khas dari setiap universitas. Kedua, dalam mengimplementasikan pendidikan karakter yang berkesinambungan, mahasiswa dalam mengikuti perkuliahan MKU masih mengeluhkan hampir $70 \%$ model pendidikan karakter yang diterapkan disampaikan oleh dosen bersifat teoretis, artinya dalam pembelajaran daya kreativitas, keterampilan kewarganegaraan dan tanggung jawabnya masih sebatas pengetahuan saja (teks book) sehingga ketercapaian berkisar antara $30 \%$ 
pada tataran sikap masih rendah. Ketiga, 73\%, Dosen memerlukan pendampingan dalam menemukan, menerapkan dan mengevaluasi model pendidikan karakter bangsa berbasis nasionalisme, harapannya $27 \%$ yang sudah menerapkan pendidikan karakter di kampus dapat meningkat lebih tajam untuk memberikan dasar pengetahuan, keterampilan, pengalaman belajar yang

\section{Metode}

Penelitian ini dilaksanakan di seluruh PTN / PTS se-Jawa Tengah. Penelitian ini termasuk jenis penelitian dan pengembangan (research \& development). Penelitian pengembangan seringkali digunakan dalam dunia industri untuk meningkatkan kualitas dan produktifitas produk maupun model (Gall, Borg, \& Gall, 2007; Sukmadinata, 2005).

Data yang akan dikumpulkan terdiri dari data primer dan data sekunder. Data primer berupa informasi mengenai pelaku/ informan, tempat, dan peristiwa (melalui site inspection). Informan terdiri dari pengampu mata kuliah PKN dan mahasiswa yang mengambil mata kuliah PKN disemester Genap 2018/ 2019. Teknik pengumpulan data dikumpulkan dengan menggunakan beberapa metode, yakni observasi lapangan dengan pengamatan terlibat (participant observation), FGD (Focus Group Discussion), wawancara mendalam (in-depth interview), dan metode dokumenter (documentary study). Teknik sampling yang digunakan dalam penelitian ini adalah purposive sampling (sampling bertujuan). Teknik analisis yang akan digunakan dalam penelitian kualitatif ini akan didasarkan pada model analisis interaktif (Miles \& Huberman, 1992). Menurut model ini dalam pengumpulan data peneliti selalu membuat reduksi data dan sajian data secara terus menerus sampai tersusun suatu kesimpulan.

\section{Hasil dan Pembahasan}

Visi Pendidikan Kewarganegaraan di perguruan tinggi adalah merupakan sumber nilai dan pedoman dalam pengembangan dan penyelenggaraan program studi, guna mengantarkan mahasiswa memantapkan kepribadiannya sebagai manusia seutuhnya. membangun integritas sosial serta mewujudkan karakter nasional yang banyak menggali nilai kearifan lokal.Tujuan jangka panjang yang ingin dicapai dalam penelitian ini adalah adanya sebuah desain pengembangan model pembelajaran pendidikan kewarganegaraan untuk meningkatkan karakter masyarakat Indonesia di era media digital.

Ada dua misi utama program studi pendidikan kewarganegaraan di perguruan tinggi, yaitu misi pengembangan keilmuan, dan pengembangan professional. Kedua misi tersebut dimaksudkan secara umum untuk mencapai tujuan akhir yakni membentuk warga negara yang cerdas dan baik yang memantapkan kepribadiannya agar secara konsisten mampu mewujudkan nilai-nilai dasar pancasila, rasa kebangsaan, dan cinta tanah air dalam menguasai, menerapkan, dan mengembangkan ilmu pengetahuan, teknologi, dan seni dengan rasa tanggung jawab dan bermoral. Untuk menjalankan misinya dalam pengembangan keilmuan, program studi perlu bergandengan tangan dengan bersama asosiasi sebagai wahana berkumpulnya community of scholar yang diharapkan memiliki visi dan misi yang sama (Sapriya, 2015).

Pendidikan kewarganegaraan tidak hanya terdiri dari pengetahuan, nilai dan keterampilan, tetapi juga mencakup penerapan pengetahuan, nilai, dan keterampilan dalam situasi kehidupan nyata dengan berpartisipasi secara aktif (Doğanay, 2012). Peran pendidikan kewarganegaraan secara substantif tidak saja mendidik generasi muda menjadi warga negara yang cerdas dan sadar akan hak dan kewajibannya dalam konteks kehidupan bermasyarakat, berbangsa, dan bernegara yang merupakan penekanan dalam istilah pendidikan kewarganegaraan, melainkan juga membangun kesiapan warga negara untuk menjadi warga dunia (Doğanay, 2012; Winataputra, 2014)

Berdasar hal di atas, pendidikan kewarganegaraan di Indonesia juga berkontribusi penting dalam menunjang tujuan bernegara Indonesia. Pendidikan kewarganegaraan secara sistematik adalah dalam rangka perwujudan fungsi dan tujuan 
pendidikan nasional berdasarkan Pancasila dan UUDNRI 1945. Pendidikan kewarganegaraan berkaitan dan berjalan seiring dengan perjalanan pembangunan kehidupan berbangsa dan bernegara.

Pendidikan kewarganegaraan merupakan bagian integral dari ide, instrumentasi, dan praksis kehidupan bermasyarakat, berbangsa, dan bernegara Indonesia (Somantri \& Winataputra, 2017). Bahkan dikatakan, pendidikan nasional kita hakikatnya adalah pendidikan kewarganegaraan agar dilahirkan warga negara Indonesia yang berkualitas baik dalam disiplin sosial dan nasional, dalam etos kerja, dalam produktivitas kerja, dalam kemampuan intelektual dan profesional, dalam tanggung jawab kemasyarakatan, kebangsaan, kemanusiaan serta dalam moral, karakter dan kepribadian (Soedijarto, 2008). Pendidikan kewarganegaraan merupakan bidang yang lintas keilmuan (Winataputra, 2001) atau bidang yang multidisipliner (Sapriya, 2007). Sebagai bidang yang multidimensional, pendidikan kewarganegaraan dapat memuat sejumlah fungsi antara lain sebagai pendidikan politik, pendidikan hukum dan pendidikan nilai (Soemantri, 2001), pendidikan demokrasi (Winataputra, 2001) pendidikan nilai, pendidikan demokrasi, pendidikan moral dan pendidikan Pancasila (Al-Muchtar, 2005), dan sebagai pendidikan demokrasi, pendidikan karakter bangsa, pendidikan nilai dan moral, pendidikan bela negara, pendidikan politik, dan pendidikan hukum (Sapriya, 2007). Fungsi yang berbeda-beda tersebut sejalan dengan karakteristik "warga negara yang baik" yang hendak diwujudkan.

Pembelajaran

Pendidikan

Kewarganegaraan di perguruan tinggi memiliki peranan penting dalam proses pendidikan yang mampu menggali seluruh potensi individu secara cerdas dan efektif demi terbentuknya masyarakat yang sejahtera lahir dan batin. Untuk itu, diperlukan pembaharuan/reformasi konsep dan paradigma pembelajaran PKn dari yang hanya menekankan pada aspek kognitif menjadi penekanan pada pengembangan warga negara yang cerdas, demokratis, dan religius serta memiliki karakteristik yang multi- dimensional.

Pembaharuan

dalam

pembelajaran PKn tersebut diharapkan dapat menjadikan mahasiswa sebagai young citizen atau warga negara yang cerdas, kreatif, partisipatif, prospektif, dan bertanggung jawab agar mampu memberikan masukan terhadap kebijakan publik di lingkungannya. Dari pemaparan tersebut, dapat kita ketahui bahwa selama ini proses pembelajaran Pendidikan Kewarganegaraan lebih menekankan aspek kognitif dibandingkan dengan aspek afektif (Narvaez, Bock, Endicott, \& Lies, 2004). Seharusnya pembelajaran Pendidikan Kewarganegaraan meliputi 3 (tiga) aspek, yaitu kognitif, afektif dan psikomotor. Untuk itu diperlukan pembenahan terhadap internalisasi nilai, dan karakter seseorang. Studi pendahuluan bertujuan untuk mendeskripsikan desain pengembangan model pembelajaran $\mathrm{PKn}$, permasalahan yang muncul dan kebutuhan desain model pembelajaran untuk meningkatkan karakter mahasiswa, serta merancang draf desain model pembelajaran untuk pendidikan karakter.

Draf desain yang dikembangkan berdasarkan orientasi komponen model yang terdiri dari: langkah PBM, model pembelajaran, prinsip pembelajaran, system penunjang, dampak instruksional dan dampak pengiring. Kegiatan yang dilakukan dalam mencapai tujuan tersebut adalah dengan melakukan studi pustaka dan penelitian dalam skala kecil. Studi pustaka dan survei lapangan digunakan untuk penyusunan draf awal desain yang selanjutnya diulas dalam sebuah pertemuan yang dihadiri oleh para ahli. Berdasarkan masukan-masukan hasil pertemuan tersebut, peneliti mengadakan penyempurnaan draf desain pengembangan. Draf desain pengembangan model yang sudah disempurnakan kemudian digandakan sesuai dengan kebutuhan.

\section{Hasil Desain Pengembangan Model \\ Pembelajaran Pendidikan \\ Kewarganegaraan}

Langkah-langkah prosedural yang dilakukan menggunakan desain pengembangan menurut model $A D D I E$ (Analysis-Design-Develop-Implement-

Evaluate). Desain merupakan langkah kedua 
dari model desain pembelajaran MPC yaitu dengan menentukan pengalaman belajar yang perlu dimiliki oleh mahasiswa selama mengikuti aktivitas pembelajaran. Mahasiswa mampu mencapai tingkat kompetensi 60\% dari standar kompetensi, indikator, kondisi pembelajaran, dan bahan ajar yang telah digariskan. Pengembangan merupakan langkah ketiga dalam mengimplementasikan model pembelajaran MPC yang mencakup kegiatan memilih, menentukan metode, media serta strategi pembelajaran yang sesuai untuk digunakan dalam menyampaikan materi atau substansi program sesuai dengan pokok materi dan kompetensi dasar yang akan dicapai. Langkah berikutnya yaitu Implementasi atau penyampaian materi pembelajaran yang merupakan langkah keempat dari model pembelajaran MPC untuk membimbing mahasiswa untuk mencapai tujuan atau kompetensi. Selanjutnya menjamin terjadinya pemecahan masalah/solusi untuk mengatasi kesenjangan hasil belajar yang dihadapi oleh mahasiswa dan terakhir memastikan bahwa pada akhir program pembelajaran mahasiswa perlu memiliki kompetensi pengetahuan, sikap, dan keterampilan yang diperlukan berkaitan dengan nilai-nilai karakter pada aspek civic knowledge, civic skill dan civic disposition. Dalam hal ini ditetapkan langlah-langkah sebagai berikut yakni (1) penjelasan tentang informasi sesuai dengan sajian kompetensi dasar (2) mengidentifikasi masalah berbasis pada nilai karakter (3) memilih suatu masalah untuk dikaji oleh kelas berbasis pada nilai karakter; (4) mengumpulkan informasi yang terkait pada masalah itu; (5) mengembangkan portofolio kelas berbasis pada nilai karakter; (6) menyajikan portofolio; (7) melakukan refleksi pengalaman belajar berbasis pada nilai karakter (Trisiana et al., 2015). Pada tahap Evaluasi, yang terjadi pada tahap ke empat dengan melakukan evaluasi formatif karena tujuannya untuk kebutuhan revisi. Evaluasi terhadap program pembelajaran MPC bertujuan untuk mengetahui sikap mahasiswa terhadap kegiatan pembelajaran secara keseluruhan. Peningkatan kompetensi dalam diri mahasiswa, yang merupakan dampak dari keikutsertaan dalam program pembelajaran.

\section{Desain Pembelajaran Berbasis Media Digital Di Era Revolusi Teknologi}

Pengembangan sistem instruksional adalah suatu proses secara sistematis dan logis untuk mempelajari problem-problem pembelajaran, agar mendapatkan pemecahan yang teruji keandalannya dan praktis bisa dilaksanakan. Sistem instruksional adalah semua materi pelajaran dan metode yang telah diuji dalam praktik yang dipersiapkan untuk mencapai tujuan dalam keadaan senyatanya. Dengan kata lain bahwa sistem instruksional merupakan tatanan aktivitas belajar mengajar. Desain instruksional adalah keseluruhan proses analisis kebutuhan dan tujuan belajar serta pengembangan teknik mengajar dan materi pengajarannya untuk memenuhi kebutuhan tersebut. Termasuk di dalamnya adalah pengembangan paket pembelajaran, kegiatan mengajar, uji coba, revisi, dan kegiatan mengevaluasi hasil belajar.

Desain sistem instruksional ialah pendekatan secara sistematis dalam perencanaan dan pengembangan sarana serta alat untuk mencapai kebutuhan dan tujuan instruksional. Semua konsep sistem ini (tujuan, materi, metode, media, alat, evaluasi) dalam hubungannya satu sama lain dipandang sebagai kesatuan yang teratur sistematis. Komponen-komponen tersebut lebih dahulu diuji coba efektivitasnya sebelum disebarluaskan penggunaannya. Pengembangan sistem instruksional adalah suatu proses menentukan dan menciptakan situasi dan kondisi tertentu yang menyebabkan siswa dapat berinteraksi sedemikian rupa sehingga terjadi perubahan di dalam tingkah lakunya (Joyce, Weil, \& Calhoun, 2015). Desain pembelajaran adalah disiplin yang berhubungan dengan pemahaman dan perbaikan satu aspek dalam pendidikan yaitu proses pembelajaran. Tujuan kegiatan membuat desain pembelajaran adalah menciptakan sarana yang optimal untuk mencapai tujuan pembelajaran yang dikehendaki. Sehingga disiplin desain pembelajaran terutama berkenaan dengan perumusan metode-metode pembelajaran yang menghasilkan perubahan yang

Jurnal Civics: Media Kajian Kewarganegaraan | 159 
diinginkan dalam pengetahuan dan keterampilan siswa.

Menurut Rauner dan Maclean (2008, hal. 49) model adalah "pengganti dari suatu sistem yang sebenarnya yang diarahkan untuk keperluan penyelidikan suatu eksperimen." Dari pendapat diatas dapat dirumuskan bahwa model adalah suatu perwakilan atau abstraksi dari sebuah objek atau situasi aktual yang memperlihatkan hubungan langsung maupun tidak langsung serta kaitan timbal balik dalam istilah sebab akibat. Model pembelajaran merupakan landasan praktik pembelajaran hasil penurunan teori psikologi pendidikan dan teori belajar yang dirancang berdasarkan analisis terhadap implementasi kurikulum dan implikasinya pada tingkat operasional di kelas. Empat rumpun model, yaitu rumpun model pemrosesan informasi (the information processing models), model personal (personal models), model interaksi sosial (social models), dan rumpun model sistem perilaku (behavioral systems). Keempat rumpun model pembelajaran yang telah dikemukakan di atas, memiliki unsur-unsur sebagai berikut yakni (1) sintaks (syntax) yaitu urutan langkah pengajaran yang menunjuk pada fase/tahap yang harus dilakukan oleh guru bila ia menggunakan model pembelajaran tertentu. Misalnya model deduktif akan menggunakan sintak yang berbeda dengan model induktif. (2) Prinsip reaksi (principles of reaction) berkaitan dengan pola kegiatan yang menggambarkan bagaimana seharusnya guru melihat dan memperlakukan para siswa termasuk bagaimana seharusnya guru memberikan respon terhadap siswa. Prinsip ini memberi petunjuk bagaimana seharusnya guru menggunakan aturan permainan yang berlaku pada setiap model. (3) Sistem sosial (the social system) adalah pola hubungan guru dengan siswa pada saat terjadinya proses pembelajaran (situasi atau suasana dan norma yang berlaku dalam penggunaan model pembelajaran tertentu). (4). Sistem pendukung (support system) yaitu segala sarana bahan dan alat yang diperlukan untuk menunjang terlaksananya proses pembelajaran secara optimal, serta (5). Dampak instruksional (instructional effect) dan dampak pengiring (nurturant effects)
(Lum, 1997). Dampak instruksional adalah hasil belajar yang dicapai atau yang berkaitan langsung dengan materi pembelajaran, sementara dampak pengiring adalah hasil belajar iringan yang dicapai sebagai akibat dari penggunaan model pembelajaran tertentu.

Perkembangan ilmu pengetahuan teknologi dari barat di Indonesia membawa dampak bagi kemajuan negara Indonesia. Masyarakat Indonesia mulai melakukan pergerakan untuk memperjuangkan kemerdekaan Indonesia. Di samping itu penggunaan ilmu pengetahuan dan teknologi di Indonesia juga membawa dampak bagi semangat juang bangsa Indonesia. Mereka memanfaatkan ilmu pengetahuan dan teknologi modern untuk mencari informasiinformasi terkini mengenai keadaan dunia. Oleh karena itu masyarakat Indonesia benarbenar terbantu dengan perkembangan ilmu pengetahuan dan teknologi (Nasrullah, 2016).

Pada masa kolonial perkembangan ilmu pengetahuan dan teknologi belum begitu maksimal. Pemerintah kolonial menjadi penyebab perkembangan ilmu pengetahuan dan teknologi di Indonesia. Pemerintah kolonial menghalangi akses masuknya ilmu pengetahuan dan teknologi dari barat ke Indonesia. Mereka juga melakukan pelarangan terhadap pendidikan bagi masyarakat Indonesia untuk mempelajari ilmu pengetahuan dan teknologi. Akibatnya Indonesia tertinggal jauh dengan negaranegara di sekitarnya. Secara keseluruhan penyebab lain dari ketertinggalan Indonesia dalam bidang ilmu pengetahuan dan teknologi adalah sebagai berikut yakni (a) terbatasnya jumlah orang Indonesia yang mendapat pendidikan terutama pendidikan tinggi, (b) masyarakat indonesia jarang terlibat langsung dalam pengembangan iptek, (c) pemerintah Belanda dan perusahaan-perusahaan yang berada di Indonesia untuk melakukan alih teknologi, (d) minimnya industrialisasi, dan (e) kurangnya inovasi teknologi yang berarti di dalam masyarakat Indonesia sendiri. Setelah merdeka, perkembangan ilmu pengetahuan dan teknologi berkembang pesat di Indonesia, hal ini didorong dengan terbukanya akses-akses untuk mendapatkan 
ilmu pengetahuan dan teknologi bagi masyarakat di Indonesia. Kemerdekaan menciptakan keadilan dan kemudahan dalam mengakses ilmu pengetahuan dan teknologi bagi masyarakat di Indonesia.

Mayer (2008) berpendapat bahwa pendidikan memerlukan "linking science" antara teori belajar dan praksis pendidikan. Desain pembelajaran dianggap sebagai penghubung antara keduanya karena desain pembelajaran adalah pengetahuan yang merumuskan tindakan pembelajaran untuk mencapai outcome pembelajaran. Aspek desain pembelajaran meliputi dua wilayah utama yaitu (1) psikologi, khususnya teori belajar, dan (2) media dan komunikasi. Tetapi media dan komunikasi seakan memberikan kontribusi prinsip dan strategi secara terpisah pada desain pembelajaran, tidak seperti teori belajar yang memberikan model terintegrasi. Desain pembelajaran lebih banyak didukung oleh teori belajar.

Dengan bekal pengetahuan ini kemudian masyarakat Indonesia melakukan berbagai inovasi dan eksperimen ilmu pengetahuan dan teknologi untuk mengembangkan ilmu pengetahuan di Indonesia. Banyak hal yang dirasa berbeda dan berubah dibandingkan dengan cara yang berkembang sebelumnya. Saat sekarang ini jarak dan waktu bukanlah sebagai masalah yang berarti untuk mendukung pertumbuhan ekonomi, berbagai aplikasi tercipta untuk memfasilitasinya. Perekonomian suatu negara dapat dilihat dari perkembangan teknologi informasi dan komunikasi di negara tersebut. Semakin tinggi perkembangan teknologi informasi maka semakin tinggi pula pertumbuhan ekonomi negara tersebut. Namun perkembangan teknologi informasi ini juga memiliki sisi negatif, dimana banyak penyalahgunaan teknologi dalam melakukan tindak kriminal. Kemajuan teknologi adalah sesuatu hal yang tidak bisa dihindari dalam kehidupan ini, karena kemajuan teknologi akan berjalan sesuai dengan kemajuan ilmu pengetahuan. Selanjutnya menjamin terjadinya pemecahan masalah/solusi untuk mengatasi kesenjangan hasil belajar yang dihadapi oleh siswa, dan terakhir memastikan bahwa pada akhir program pembelajaran siswa perlu memiliki kompetensi pengetahuan, sikap, dan keterampilan yang diperlukan berkaitan dengan nilai-nilai karakter pada aspek civic knowledge, civic skill, dan civic disposition.

Penerapan model project citizen yang diadaptasi dari John Dewey serta dikembangkan sintaksnya dengan nama baru yaitu MPC (Modification of Project Citizen) yang dikaitkan dengan pendidikan karakter dapat menjadi alternatif untuk mengembangkan pembelajaran Pendidikan Kewarganegaraan melalui berbagai program kebijakan pemerintah, sekaligus memberikan kontribusi terhadap evaluasi program, yang disertai dengan meningkatnya partisipasi mahasiswa untuk menjadi warga negara yang terampil, kritis, dan bertanggungjawab. Langkah MPC dapat dilihat sebagai berikut.

Tabel Model Modification of Project Citizen Di Era Media Digital sebagai Pendukung Pendidikan Karakter

\begin{tabular}{l}
\hline \multicolumn{1}{c}{ Langkah MPC } \\
\hline Penelusuran informasi melalui \\
media sosial \\
Identifikasi masalah berbasis pd \\
nilai karakter
\end{tabular}

Simulasi media sosial

\section{Pembelajaran Berbasis Media Digital}

Membaca, mendengar, menyimak, dan melihat (tanpa atau dengan alat).

Mengajukan pertanyaan tentang informasi yang tidak dipahami dari apa yang diamati atau pertanyaan untuk mendapatkan informasi tambahan tentang apa yang diamati (dimulai dari pertanyaan faktual sampai ke pertanyaan yang bersifat hipotetis): Mahasiswa membuat Instrumen pedoman wawancara, dan observasi dengan dipandu oleh dosen dalam kelas.

- Melakukan eksperimen.

- Membaca sumber lain selain buku teks.

- Mengamati objek/kejadian/ aktivitas. 
Pengolahan informasi digital

Pengembangan media digital

Penyajian media digital

Refleksi pengalaman belajar digital

untuk Setiap inovasi diciptakan untuk
memberikan manfaat positif bagi kehidupan manusia. Memberikan banyak kemudahan, serta sebagai cara baru dalam melakukan aktivitas manusia. Khusus dalam bidang teknologi masyarakat sudah menikmati banyak manfaat yang dibawa oleh inovasiinovasi yang telah dihasilkan dalam dekade terakhir ini. Namun demikian, walaupun pada awalnya diciptakan untuk menghasilkan manfaat positif, di sisi lain juga memungkinkan digunakan untuk hal negatif dari kemajuan teknologi dalam kehidupan manusia.

\section{Simpulan}

Desain Model Pembelajaran Pendidikan Kewarganegaraan di Era media digital sebagai pendukung implementasi pendidikan karakter dikembangkan melalui Analyze, Design, Develop, Implement, Evaluation (ADDIE) yang dilakukan sebagai berikut, pertama, Analysis, yaitu melakukan analisis kebutuhan, mengidentifikasi masalah (kebutuhan), dan melakukan analisis tugas. Kedua, Design, yakni merumuskan tujuan pembelajaran yang SMART. Ketiga,
- Wawancara dengan nara sumber sesuai dengan lokasi masing-masing daerah.

- Mengolah informasi yang sudah dikumpulkan baik terbatas dari hasil kegiatan mengumpulkan/eksperimen maupun hasil dari kegiatan mengamati dan kegiatan mengumpulkan informasi.

- Pengolahan informasi yang dikumpulkan dari yang bersifat menambah keluasan dan kedalaman sampai kepada pengolahan informasi yang bersifat mencari solusi dari berbagai sumber yang memiliki pendapat yang berbeda sampai kepada yang bertentangan.

Menyampaikan hasil pengamatan, kesimpulan berdasarkan hasil analisis secara lisan, tertulis, atau media lainnya: membuat catatan lapangan hasil wawancara (CLHW).

Memodifikasi, menyusun kembali untuk menemukan yang baru, dan menemukan yang baru secara original.

Dosen, bersama mahasiswa, dan Stakeholders melakukan hasil penilaian terhadap refleksi hasil pembelajaran.

il penelitian, 2018

Development, adalah proses mewujudkan blue-print. Keempat, Implementation, adalah langkah nyata untuk menerapkan sistem pembelajaran yang sedang kita buat. Kelima, Evaluation, yaitu proses untuk melihat apakah sistem pembelajaran yang sedang dibangun berhasil, sesuai dengan harapan awal atau tidak. Evaluasi merupakan langkah terakhir dari model desain sistem pembelajaran ADDIE. Berdasarkan pengembangan instruksional model ADDIE tersebut kemudian diadopsi dalam tahapan pengembangan model pembelajaran Project Citizen (PC) dengan nama baru MPC (Modification of Project Citizen). Kompetensi pendidikan kewarganegaraan khususnya civic virtue menjadi bagian yang tak terpisahkan dari revolusi teknologi dalam memahami dan menerapkan nilai karakter secara bertanggung jawab.

\section{Ucapan Terima Kasih}

Penulis mengucapkan terima kasih kepada Direktorat Penelitian dan Pengabdian Pada Masyarakat Kemenristekdikti yang telah memberikan pendanaan pada penelitian dasar anggaran Tahun 2019. Ucapan terima kasih 
juga disampaikan pada Rektor Universitas Slamet Riyadi Surakarta yang telah memfasilitasi terlaksananya kegiatan penelitian ini.

\section{Referensi}

Al-Muchtar, S. (2005). Pengajaran mikro: pendekatan praktis dalam menyiapkan pendidik profesional. Yogyakarta: Tiara Wacana.

Arthur, J., Kristjánsson, K., Harrison, T., Sanderse, W., \& Wright, D. (2016). Teaching character and virtue in schools. London: Routledge.

Arthur, J., Kristjánsson, K., Walker, D., Sanderse, W., Jones, C., Thoma, S., ... Roberts, M. (2015). Character education in UK school. research report. Birmingham: University of Birmingham.

Aslan, M. (2011). Handbook of moral and character education, edt. Larry P. Nuci and Darcia Narvaez. International Journal of Instruction, 4(2), 211-214. https://doi.org/10.4324/9780203931431

Carr, D., Arthur, J., \& Kristjánsson, K. (Ed.). (2017). Varieties of virtue ethics. London: Palgrave Macmillan. https://doi.org/10.1057/978-1-13759177-7_2

Doğanay, A. (2012). A curriculum framework for active democratic citizenship education. In M. Print \& D. Lange (Ed.), School, curriculum and civic education for building democratic citizens (hal. 1939). Roterdam, Boston, Taipe: Sense Publisher.

Gall, M. D., Borg, W. R., \& Gall, J. P. (2007). Educational research: an introduction (8th ed.). Allyn \& Bacon,.

Joyce, B., Weil, M., \& Calhoun, E. (2015). Model of teaching (9th ed.). New York: Allyn and bacon a Pearson Education Company.

Lum, B. J. (1997). Student mentality: intentionalist perspectives about the principal. Journal of Education Administration, 35(3).

Martens, H., \& Hobbs, R. (2015). How media literacy supports civic engagement in a digital age. Atlantic Journal of Communication, 23(2), 120-137. https://doi.org/10.1080/15456870.2014. 961636

Mayer, R. E. (2008). Learning and instruction. New Jersey: Pearson Merrill Prentice Hall. Diambil dari https://books.google.co.id/books?id=DP pkSwAACAAJ

Miles, M. B., \& Huberman, A. M. (1992). Analisis data kualitatif. Jakarta: Universitas Indonesia Press.

Narvaez, D., Bock, T., Endicott, L., \& Lies, J. (2004). Minnesota's community voices and character education project. Journal of Research in Character Education, 2(2), 89-112.

Nasrullah, R. (2016). Media sosial perspektif komunikasi, budaya, dan sosioteknologi. Bandung: Simbiosa Rekatama Media.

Prewitt, K., Dawson, R. E., \& Dawson, K. (1977). Political socialization. Boston: Little Brown and Company.

Rauner, F., \& Maclean, R. (Ed.). (2008). Handbook of technical and vocational education and training research. Springer. https://doi.org/10.1007/978-14020-8347-1

Sapriya. (2007). Perspektif pemikiran pakar tentang pendidikan kewarganegaraan dalam membangun karakter bangsa. Universitas Pendidikan Indonesia, Bandung.

Sapriya. (2015). Pengembangan kurikulum program studi PKn sebagai disiplin ilmu terintegrasi berbasis KKNI. In Sapriya, C. Darmawan, Syaifullah, M. M. Adha, \& C. Cuga (Ed.), Prosiding Seminar Nasional Penguatan Komitmen Akademik dalam Memperkokoh Jatidiri Pendidikan Kewarganegaraan (hal. 7694). Bandung: Laboratorium Pendidikan Kewarganegaraan-Universitas Negeri Yogyakarta.

Soedijarto. (2008). Landasan dan arah pendidikan nasional kita. Jakarta: Penerbit Buku Kompas. Diambil dari https://books.google.co.id/books?id=9K GqRIq6JtYC

Soemantri, M. N. (2001). Menggagas pembaruan pendidikan IPS. Bandung: PT. Remaja Rosdakarya.

Somantri, M. N., \& Winataputra, U. S. (2017). 
Disiplin pendidikan kewarganegaraan: Kultur akademis dan pedagogis. (Sapriya \& R. Machfiroh, Ed.) (Edisi pert). Bandung: Laboratorium Pendidikan Kewarganegaraan Universitas Pendidikan Indonesia.

Sukmadinata, N. S. (2005). Metode penelitian pendidikan. Bandung: PT. Remaja Rosdakarya.

Trisiana, A. (2016). Analysis of character education policy in Indonesian school to improve the ASEAN Economic Community. Research Journal of Applied Sciences ( RJAS), 11(9), 879883.

Trisiana, A., Jutmini, S., Haryati, S., \& Hidayatullah, F. (2015). The development strategy of citizenship education in civic education using project citizen model in Indonesia. Journal of Psychological \& Educational Research, 23(2), 111-124.

Winataputra, U. S. (2001). Jatidiri pendidikan kewarganegaraan sebagai pendidikan demokrasi. Disertasi. Sekolah Pascasarjana Universitas Pendidikan Indonesia.

Winataputra, U. S. (2014). Pendidikan kewarganegaraan dalam perspektif internasional. Jurnal Acta Civicus, 1.

Winataputra, U. S. (2015). Pendidikan kewarganegaraan: refleksi historisepistemologis dan rekonstruksi untuk masa depan (1 ed.). Tangerang Selatan: Universitas Terbuka. 